\title{
Use of quantum dots of sizes magic in biological systems
}

\author{
Samantha Deus ${ }^{1 *}$, Felipe Luz $^{2}$, Anielle Silva ${ }^{3}$, Noelio Dantas ${ }^{3}$, Marcelo Silva ${ }^{2}$ \\ From 5th Congress of the Brazilian Biotechnology Society (SBBIOTEC) \\ Florianópolis, Brazil. 10-14 November 2013
}

QDs are inorganic semiconductor nanocrystals with quantum confinement and physical and chemical properties different from their counterparts. These properties are controlled depending on the size, shape and structure of nanocrystals, which can absorb and emit a predetermined range of the electromagnetic spectrum. QDs measure 2-10 $\mathrm{nm}$ but was recently created the MSNs QDs (nanocrystals sizes magicians), measuring 1-2 nm with well-defined structures, high stability during and after the growth, the presence of a few unit cells in their composition, show strong quantum confinement and different thermodynamically stable structures. In biomarkers, MSNs QDs have several advantages over organic dyes: exhibit high molar absorption absorption spectrum continuous, high intensity luminance and high stability. Therefore QDs may be used in nanomedicine detection of cancers. Once injected into the body dialing UV indicate the location of the tumor devices that capture this fluorescence particle, greatly improving diagnostic procedures. Therefore, the objective is to improve the QDs MSNs for use in biological systems. Laboratory of New Insulating Materials and Semiconductors (LNMIS) were synthesized, probably for the first time. These QDs were tested in HeLa cells and Ehrlich. The results showed that are stable after 4 years the synthesis. In vitro assays showed high fluorescence scattered throughout the cytoplasm, demonstrated by doublelabeling with DAPI, up to 20 hours after incorporation by the cell. Thus, incorporation of these QDs by tumor cells and their stability allows them to be used in studies of tumor cell migration in vivo.

\section{Authors' details}

'Instituto de Genética e Bioquímica (INGEB), Universidade Federal de Uberlândia, Santa Mônica, Uberlândia, MG, Brazil. ${ }^{2}$ Instituto de Ciências Biomédicas (ICBIM), Universidade Federal de Uberlândia, Santa Mônica, Uberlândia, MG, Brazil. ${ }^{3}$ Instituto de Física (INFIS), Universidade Federal de Uberlândia, Santa Mônica, Uberlândia, MG, Brazil.

Published: 1 October 2014

\section{References}

1. Chen X, Samia ACS, Lou Y, Burda C: Investigation of the Crystallization Process in $2 \mathrm{~nm}$ CdSe Quantum Dots. J Am Chem Soc 2005, 127:4372-4375

2. Mcbride JR, Dukes AD III, Schreuder MA, Rosenthal SJ: On ultrasmallnanocrystals. Chem Phy Lett 2010, 498:1-9.

3. Nurbosyn J, Zhanpeisov U, Fukumura H, Baba Y, Rajan MI: Structure Property Correlation of CdSe Clusters Using Experimental Results and First-Principles DFT Calculations. J Am Chem Soc 2006, 128:629-636.

4. Soloviev VN, Eichhofer A, Fenske D, Banin U: Molecular Limit of a Bulk Semiconductor: Size Dependence of the "Band Gap" in CdSe Cluster Molecules. J Am Chem Soc 2000, 122:2673-2674.

5. Ute RG, Markus G, Sara CJ, Roland N, Thomas N: Quantum dots versus organic dyes as fluorescent labels. Nature Methods 2008, 5(9):763-775.

doi:10.1186/1753-6561-8-S4-P258

Cite this article as: Deus et al.: Use of quantum dots of sizes magic in biological systems. BMC Proceedings 2014 8(Suppl 4):P258.

'Instituto de Genética e Bioquímica (INGEB), Universidade Federal de Uberlândia, Santa Mônica, Uberlândia, MG, Brazil

Full list of author information is available at the end of the article

Submit your next manuscript to BioMed Central and take full advantage of:

- Convenient online submission

- Thorough peer review

- No space constraints or color figure charges

- Immediate publication on acceptance

- Inclusion in PubMed, CAS, Scopus and Google Scholar

- Research which is freely available for redistribution
() Biomed Central
C Biomed Central

(c) 2014 Deus et al.; licensee BioMed Central Ltd. This is an Open Access article distributed under the terms of the Creative Commons Attribution License (http://creativecommons.org/licenses/by/4.0), which permits unrestricted use, distribution, and reproduction in any medium, provided the original work is properly cited. The Creative Commons Public Domain Dedication waiver (http://creativecommons.org/publicdomain/zero/1.0/) applies to the data made available in this article, unless otherwise stated. 